\title{
Performance and Carcass Characteristics of Broiler Chickens with Different Growth Potential and Submitted to Heat Stress
}

Author(s)
Rosa PS ${ }^{1,2}$
Faria Filho $\mathrm{DE}^{3}$
Dahlke $\mathrm{F}^{4}$
Vieira $\mathrm{BS}^{2}$
Macari $\mathrm{M}^{2}$
Furlan $\mathrm{RL}^{2^{*}}$
1 Embrapa Suínos e Aves and Universidade
do Contestado, UnC, Concórdia, Santa
Catarina, Brasil.
2 Universidade Estadual Paulista, Faculdade
de Ciências Agrárias e Veterinárias,
Departamento de Morfologia e Fisiologia
Animal, Jaboticabal, São Paulo, Brasil.
Universidade Federal de Minas Gerais,
Núcleo de Ciências Agrárias, Montes Claros,
Minas Gerais, Brasil
4 Universidade Federal do Paraná,
Departamento de Zootecnia, Curitiba,
Paraná, Brasil.

Mail Address

Renato Luis Furlan
Universidade Estadual Paulista
Faculdade de Ciências Agrárias e Veterinárias,
Departamento de Morfologia e Fisiologia
Animal.
Via de Acesso Prof. Paulo Donato Castellane,
s/n
14.884-900. Jaboticabal, São Paulo, Brasil.
E-mail:rlfurlan@fcav.unesp.br

Keywords

Allometric coefficient, carcass yield, genetic improvement, heat stress.

\section{ABSTRACT}

In order to evaluate the effects of broiler genotype and of heat exposure on performance, carcass characteristics, and protein and fat accretion, six hundred one-day-old male broilers were randomly assigned in a $2 \times 3$ factorial arrangement, according to the following factors: genetic group (selected and non-selected broilers) and pair-feeding scheme $\left(\mathrm{Ad}_{32}\right.$ - reared under heat stress and fed ad libitum; $\mathrm{Ad}_{23}$ - reared at thermoneutrality and fed ad libitum; $\mathrm{Pf}_{23}$ - reared at thermoneutrality and pair fed with $\mathrm{Ad}_{32}$ ), with a total of six treatments with four replicates of 25 birds each. Independent of pair-feeding scheme, selected broilers showed better feed conversion, higher carcass yield, and lower abdominal fat deposition rate. However, as compared to non-selected broilers, they reduced more intensively feed intake when heat exposed, which promoted significant breast-yield decrease, and more pronounced changes on carcass chemical composition. These findings allows concluding that, in both genetic groups, both environmental temperature and feed-intake restriction influence abdominal fat deposition rate and other carcass characteristics; however, the impact of heat exposure on broiler performance is more noticeable on the selected line.

\section{INTRODUCTION}

Harsh environmental conditions result in important economic losses for the poultry industry in tropical countries. Heat exposure impairs broilers performance, especially during growing and finishing periods, as their ability to dissipate heat decreases according to body growth. The primary consequence of heat exposure is reduction in feed intake (Geraert et al., 1996a), a physiological response in order to decrease metabolic heat production and to maintain body homeostasis (Koh \& Macleod, 1999). However, heat exposure also impairs survival rate (Deaton et al., 1986), weight gain, and feed conversion ratio of broiler flocks (Geraert et al., 1993, Faria Filho, 2006), which have a direct impact on the profitability of this activity. Moreover, lower breast yield and higher fat deposition were described in broilers exposed to heat (Ain Baziz et al., 1996; Geraert et al., 1996a), which are undesirable, considering the economic value of breast meat and that excessive amount of fat in broiler carcasses is not well accepted by customers.

Broiler genotype is another factor that influences performance. During the last decades, weight gain, feed conversion ratio, protein accretion, as well as both carcass and breast yield have improved by selection programs (Chambers et al., 1981; Havenstein et al., 1994a, 1994b). Nevertheless, this continuous selection for weight gain decreased broiler ability to cope with heat. In fact, as metabolic heat production is highly associated with protein accretion (Macleod, 1997), fast-growing broilers might have more difficulties to maintain body 
Rosa PS, Faria Filho DE, Dahlke F, Vieira BS, Macari M, Furlan RL
Performance and Carcass Characteristics of Broiler Chickens with Different Growth Potential and Submitted to Heat Stress homeostasis under high environmental temperatures. Consequently, when heat-exposed, the performance of slow-growing male broilers is not as impaired as that of the fast-growing ones (Leenstra \& Cahaner, 1992).

Unfortunately, little information on the interaction between environmental temperature and broiler genotype is available in literature. It is important to determine the extent of heat tolerance decrease in broilers caused by genetic selection in order to develop and to apply new strategies both in genetic selection programs and broiler production units. Therefore, this study aimed at quantifying the impact of heat exposure on performance and carcass characteristics, comparing the responses of broilers with different growth potential.

\section{MATERIAL AND METHODS}

\section{Birds and management}

Eggs from a commercial strain (AgRoss 308) and from a non-selected meat line (PCLC - an Embrapa experimental line maintained by random mating since 1984) were incubated according to commercial practices in a Petersime machine with capacity of 5,000 eggs. The initial chick weights were $43.9 \pm 0.03$ $\mathrm{g}$ and $41.7 \pm 0.03 \mathrm{~g}$ for PCLC and AgRoss 308, respectively.

Chicks were reared in two environmental controlled rooms: one maintained at thermoneutral temperature (Ross Broiler Management Manual), and the other at $32^{\circ} \mathrm{C}$ (heat-stress) throughout the experimental period. All broilers reared under heat-stress conditions were fed ad libitum. Broilers reared at thermoneutrality were divided into two groups: one was fed ad libitum, and the other was fed with the same amount of feed consumed by the heat-stressed group, in a pair-feeding scheme. This procedure was daily adjusted, and aimed at separating the direct effects of environmental temperature and feed-intake reduction from the total effect of heat exposure.

A starter diet was offered up to 21 days of age, and a grower diet from 22 to 42 days of age. Both feeds were based on corn and soybean meal, and formulated according to the NRC (1994) requirements. Light was continuously provided (24h/day) throughout the experimental period. Water was offered ad libitum.

\section{Experimental design and data collection}

Six hundred one-day-old male chicks were randomly placed in floor pens according to a $2 \times 3$ factorial design, with factors: genetic group (AgRoss 308 or PCLC) and pair-feeding scheme $\left(\mathrm{Ad}_{32}\right.$ - reared at heat stress and fed ad libitum; $\mathrm{Ad}_{23}$ - reared at thermoneutrality and fed ad libitum; $\mathrm{Pf}_{23}$ - reared at thermoneutrality and pair-fed with $\mathrm{Ad}_{32}$ ), totalizing six treatments with four replicates of 25 birds each.

At 42 days of age, feed intake, weight gain, and feed conversion ratio were evaluated per replicate. Moreover, for carcass trait assessment, one broiler per pen was randomly selected and sacrificed after 5-hour water and feed deprivation. Carcasses were defeathered and eviscerated, and liver, heart, gizzard, and abdominal fat were immediately weighed. Cleaned carcasses (without head, neck and feet) and parts (breast, thighs+drumsticks, and wings) were than weighed, and all the values were expressed as percentages of live body weight.Carcasses were then stored in labeled plastic bags, and frozen at $-20{ }^{\circ} \mathrm{C}$ for further chemical analysis. Dry matter, crude protein (micro-Kjeldahl), and ether extract (Soxhlet) contents were determined according AOAC (1990) recommendations.

\section{Statistics}

Data were first tested for normality (Shapiro-Wilk test) and homogeneity of variances (Levene's test). As these assumptions were not violated, data were submitted to analyses of variance, and when statistical difference was detected $(p<0.05)$, means were compared by Tukey's test at $5 \%$ probability. Inside the pair-feeding scheme, total effect of heat exposure was obtained by comparing groups $\mathrm{Ad}_{32}$ and $\mathrm{Ad}_{23}$. In addition, the direct effects of temperature and feedintake reduction were achieved by comparing $\mathrm{Ad}_{32}$ to $\mathrm{Pf}_{23}$ and $\mathrm{Ad}_{23}$ to $\mathrm{Pf}_{23}$, respectively. Data were expressed as mean \pm Standard Error of the Mean (SEM).

Abdominal fat was evaluated by the allometric coefficient $\beta$ using the following allometric growth equation: $\log y$ (abdominal fat) $=\alpha+\beta[\log x$ (body weight)], as proposed by Huxley (1932) and Huxley \& Teissier (1936). To assess allometric nature, the hypothesis $\beta=1$ vs $\beta>1$ was tested by Student's t-test. Thus, $\beta=1$ indicates similar velocities for fat deposition and body growth, and $\beta>1$ indicates that fat deposition is faster than body growth. All statistics were performed using the Statistical Analysis System - SAS ${ }^{\circledR}$ (Littell et al., 2002).

\section{RESULTS AND DISCUSSION}

\section{Growth performance}

Feed intake data were neither normal nor 
Rosa PS, Faria Filho DE, Dahlke F, Vieira BS, Macari M, Furlan RL
Performance and Carcass Characteristics of Broiler Chickens with Different Growth Potential and Submitted to Heat Stress homoscedastic; hence, variance analysis was not applied. Feed intake mean \pm SEM (g) of groups $\mathrm{Ad}_{23}$ and $\mathrm{Ad}_{32}$ were, respectively, 3,206 \pm 48.7 and 2,634 \pm 24.1 (PCLC), and 4,517 \pm 48.8 and 3,413 \pm 109.4 (AgRoss 308). Heat exposure resulted in $17.8 \%$ and $24.4 \%$ reduction in PCLC and AgRoss 308 feed intake, respectively, which may indicate that a way of avoiding heat production associated with feed consumption (Koh \& Macleod, 1999). It is important to consider that selected broilers consumed more feed, which causes higher heat production, and probably contributed to the greater reduction in feed intake.

A significant interaction $(p<0.05)$ was found between pair-feeding scheme and genetic groups for body weight (Table 1). Analyzing commercial broilers first, the contrast Ad versus Pf shows that their body weight was not affected by envirionmental temperature $(p=0.47)$. Working in a similar pair-feeding scheme, Abu-Dieyeh (2006) attributed $14 \%$ of total growth rate depression in heat-exposed male broilers $\left(35^{\circ} \mathrm{C}\right)$ to the effect of temperature per se, which may induce physiological changes, such as inefficient digestion and impaired metabolism. Not only the higher environmental temperature, but also the differences in heat exposure duration could explain such discrepant results. In the present study, broilers were exposed to high environmental temperature since placement, whereas the heat stress imposed by the above mentioned author started only on day 28. Heat exposure during the starter period, when it does not represent an significant constrain for poultry survival, may lead to heat adaptation (Arjona et al., 1988; Yahav \& McMurtry, 2001; Furlan \& Macari, 2002), and explain the lack of temperature effect in the commercial line. On the other hand, broilers of the non-selected line increased body weight $(p=0.03)$ even when submited to high temperature exposure.

In literature, other authors often showed that the decrease in weight gain due to heat exposure is more related to the reduction in feed intake than to the direct effect of temperature (Abu-Dieyeh, 2006; Ain Baziz et al., 1996; Geraert et al., 1996a). In the present study, our findings support this statement, as in both genetic groups the reduction in feed intake generated by heat exposure (contrast $\mathrm{Ad}_{23}$ versus $\mathrm{Pf}_{23}$ ) resulted in a significant decrease in broiler body weight.

No significant interaction was observed between pair-feeding scheme and genetic group for feed conversion ratio (Table 1). Moreover, analyzing the main effects of treatments, feed conversion ratio was not affected by pair-feeding scheme $(p=0.19)$, which indicates that neither temperature nor feed-intake reduction influenced broiler feed conversion ratio. Other authors described impaired feed conversion ratio due to a direct effect of temperature, which may be a result both of feed digestibility reduction (Bonnet et al., 1997) and of an increase of maintenance energy requirement (Sakomura et al., 2005). Again, the reasons for such divergent results are probably related to differences in heat-exposure duration and intensity. Nevertheless, independent of pair-feeding scheme, AgRoss 308 broilers showed $5.2 \%$ better feed conversion ratio than PCLC ones.

\section{Carcass, parts, and viscera yields}

There was no significant interaction between pairfeeding scheme and genetic group for carcass, thighs+drumsticks, wings, heart, liver, and gizzard yields (Table 2). Commercial broilers showed better carcass $(p<0.01)$, but lower thighs+drumsticks, wings and gizzard yields. Even though heart and liver yields were not influenced by genetic group, general analysis reveals a trend of viscera yield reduction in the selected line, in which is consistent with the goals of genetic improvement, and contributes to a better carcass yield. Havenstein et al. (1994b) also described improvement in carcass yield and decrease in viscera yield as a consequence of genetic improvement. Similarly, when

\begin{tabular}{|c|c|c|c|c|}
\hline \multirow[t]{2}{*}{ Variables } & \multirow[t]{2}{*}{ Pair-feeding scheme } & \multicolumn{2}{|c|}{ Genetic group } & \multirow[t]{2}{*}{ Mean } \\
\hline & & PCLC & AgRoss 308 & \\
\hline \multirow[t]{4}{*}{ Body weight } & $\mathrm{Ad}_{23}$ & $1658 \pm 10^{a B}$ & $2536 \pm 12^{\mathrm{aA}}$ & $2097 \pm 166$ \\
\hline & $\mathrm{Pf}_{23}^{23}$ & $1349 \pm 9^{\mathrm{CB}}$ & $1850 \pm 12^{\mathrm{bA}}$ & $1599 \pm 95$ \\
\hline & $\mathrm{Ad}_{32}^{23}$ & $1409 \pm 14^{b B}$ & $1868 \pm 34^{\mathrm{bA}}$ & $1638 \pm 89$ \\
\hline & Mean & $1472 \pm 41$ & $2085 \pm 97$ & \\
\hline \multirow[t]{4}{*}{ Feed conversion ratio } & $\mathrm{Ad}_{23}$ & $1.97 \pm 0.04$ & $1.78 \pm 0.03$ & $1.86 \pm 0.04$ \\
\hline & $\mathrm{Pf}_{23}^{23}$ & $1.94 \pm 0.03$ & $1.85 \pm 0.02$ & $1.90 \pm 0.02$ \\
\hline & $\mathrm{Ad}_{32}^{23}$ & $1.87 \pm 0.03$ & $1.83 \pm 0.03$ & $1.85 \pm 0.03$ \\
\hline & Mean & $1.92 \pm 0.02^{\mathrm{A}}$ & $1.82 \pm 0.02^{B}$ & \\
\hline
\end{tabular}

Different lower-case letters indicate difference $(\mathrm{p}<0.05)$ for the contrasts $\mathrm{Ad}_{32}$ versus $\mathrm{Pf}_{23}$ (effect of heat exposure) and $\mathrm{Ad}_{23}$ versus $\mathrm{Pf}_{23}$ (effect of reduced feed intake generated by heat exposure); different upper-case letters indicate difference $(p<0.05)$ between genetic groups. 
Rosa PS, Faria Filho DE, Dahlke F, Vieira BS, Macari M, Furlan RL
Performance and Carcass Characteristics of Broiler Chickens with Different Growth Potential and Submitted to Heat Stress

\begin{tabular}{|c|c|c|c|c|c|}
\hline \multirow[t]{2}{*}{ Variables } & \multicolumn{2}{|c|}{ Pair-feeding scheme } & \multicolumn{2}{|c|}{ Genetic group } & \multirow[b]{2}{*}{ AgRoss 308} \\
\hline & $\mathrm{Ad}_{23}$ & $\mathrm{Pf}_{23}$ & $\mathrm{Ad}_{32}$ & PCLC & \\
\hline Carcass & $68.0 \pm 1.1^{b}$ & $64.5 \pm 0.9^{c}$ & $69.8 \pm 1.1^{\mathrm{a}}$ & $64.7 \pm 0.6^{\mathrm{B}}$ & $70.1 \pm 0.7^{A}$ \\
\hline Thighs+drumsticks & $22.4 \pm 1.2^{b}$ & $22.5 \pm 0.9^{b}$ & $23.0 \pm 1.6^{a}$ & $24.0 \pm 1.2^{\mathrm{A}}$ & $21.6 \pm 0.9^{B}$ \\
\hline Wings & $8.1 \pm 0.2$ & $8.0 \pm 0.2$ & $8.3 \pm 0.2$ & $8.4 \pm 0.1^{A}$ & $7.9 \pm 0.2^{B}$ \\
\hline Heart & $0.53 \pm 0.03^{a}$ & $0.55 \pm 0.03^{a}$ & $0.42 \pm 0.03^{b}$ & $0.53 \pm 0.02$ & $0.47 \pm 0.03$ \\
\hline Liver & $1.77 \pm 0.03^{b}$ & $1.97 \pm 0.07^{a}$ & $1.60 \pm 0.06$ & $1.80 \pm 0.06$ & $1.76 \pm 0.07$ \\
\hline Gizzard & $1.40 \pm 0.08^{c}$ & $1,81 \pm 0,08^{a}$ & $1.47 \pm 0.13^{b}$ & $1.67 \pm 0.07^{A}$ & $1.46 \pm 0,11^{B}$ \\
\hline
\end{tabular}

Different lower-case letters indicate difference $(p<0.05)$ for the contrasts $\mathrm{Ad}_{32}$ versus $\mathrm{Pf}_{23}$ (effect of heat exposure) and $\mathrm{Ad}_{23}$ versus $\mathrm{Pf}_{23}($ effect of reduced feed intake generated by heat exposure); different upper-case letters indicate difference $(p<0.05)$ between genetic groups.

analyzing the direct effect of temperature on carcass and viscera yields (contrast $\mathrm{Ad}_{32}$ versus $\mathrm{Pf}_{23}$ ), heat exposure decreased heart, liver, and gizzard yields; however it increased carcass and thighs+drumsticks yields. Pair-feeding scheme did not influence wing yield. Higher carcass yield is frequently described in broilers exposed to heat, and it is explained as an indirect effect of reduced viscera and feather development (Oliveira Neto et al., 2000; Ain Baziz et al., 1996). Nevertheless, higher thighs+drumstick yield is normally associated to the oxidative metabolism of these muscles, as the use of fat as energy substrate favors their development under high temperatures (Temim et al., 1999; 2000).

The feed-intake reduction imposed by heat exposure (contrast $\mathrm{Ad}_{23}$ versus $\mathrm{Pf}_{23}$ ) decreased carcass yield, and indirectly promoted higher liver and gizzard yields. It is interesting to observed that, in the hot environment, this effect was suppressed by direct effect of temperature (contrast $\mathrm{Ad}_{23}$ versus $\mathrm{Ad}_{32}$ ), resulting in higher carcass yield.

There was significant interaction between pairfeeding scheme and genetic group for breast yield (Table 3), which was higher in commercial broilers $(p<0.01)$ within each pair-feeding group. In addition, breast yield in PCLC broilers was not influenced neither by the direct effect of temperature nor by the reduced feed intake generated by heat exposure; however it decreased in commercial broilers as a consequence of feed-intake reduction (contrast $\mathrm{Ad}_{23}$ versus $\mathrm{Pf}_{23}$ ). This result may be associated to insufficient intake of energy and nutrients, reducing the synthesis and the storage of glycogen, the most important energy source for breast muscles (Geraert et al., 1996a). Aksit et al. (2006) described a $1.5 \%$ reduction in breast yield and lower breast muscle glycogen level in 42-day-old male broilers exposed to heat $\left(34^{\circ} \mathrm{C}\right)$ since 21 days of age. As discussed before, it seems that the time when heat stress starts plays an important role in broiler responsiveness.

\begin{tabular}{|c|c|c|}
\hline \multirow[t]{2}{*}{ Pair-feeding scheme } & \multicolumn{2}{|c|}{ Genetic group } \\
\hline & PCLC & AgRoss 308 \\
\hline $\mathrm{Ad}_{23}$ & $17.2 \pm 0.1^{B}$ & $23.2 \pm 0.1^{\mathrm{aA}}$ \\
\hline $\mathrm{Pf}_{23}^{23}$ & $16.6 \pm 0.3^{B}$ & $21.5 \pm 0.3^{\mathrm{bA}}$ \\
\hline $\mathrm{Ad}_{32}$ & $17.2 \pm 0.3^{B}$ & $21.1 \pm 0.2^{\mathrm{bA}}$ \\
\hline
\end{tabular}

Different lower-case letters indicate difference $(p<0.05)$ for the contrasts $\mathrm{Ad}_{32}$ versus $\mathrm{Pf}_{23}$ (effect of heat exposure) and $\mathrm{Ad}_{23}$ versus $\mathrm{Pf}_{23}$ (effect of reduced feed intake generated by heat exposure); different upper-case letters indicate difference $(p<0.05)$ between genetic groups.

\section{Carcass chemical composition}

There was significant interaction $(p<0.05)$ between pair-feeding scheme and genetic group on carcass ether extract and crude protein (Table 4). The comparison between pair-feeding groups within each strain reveals that, both for PCLC and AgRoss broilers, carcass crude protein decreased and ether extract increased due to a direct effect of temperature (contrast $\mathrm{Ad}_{32}$ versus $\mathrm{Pf}_{23}$ ). On the other hand, feedintake reduction (contrast $\mathrm{Ad}_{23}$ versus $\mathrm{Pf}_{23}$ ) decreased carcass ether extract and increased carcass crude protein. It is well known that broilers exposed to heat show higher fat deposition (Howlider \& Rose, 1987), which has been related to the reduction on basal metabolism and physical activity, both of them probably influenced by plasmatic triiodothironine decrease and plasmatic corticosterone increase (Geraert et al., 1996b). Interestingly, although both genetic groups were similarly influenced by environmental temperature (contrast $\mathrm{Ad}_{32}$ versus $\mathrm{Pf}_{23}$ ), the percentage of change induced by feed-intake reduction (contrast $\mathrm{Ad}_{23}$ versus $\mathrm{Pf}_{23}$ ) in carcass chemical composition was higher in commercial than in nonselected broilers. Not only the greater feed-intake reduction observed in AgRoss 308 broilers due to heat exposure, but also metabolic rate differences between genetic groups, may explain these findings.

The analysis of genetic group effect within each pair-feeding group shows that AgRoss 308 broilers 
Rosa PS, Faria Filho DE, Dahlke F, Vieira BS, Macari M, Furlan RL
Performance and Carcass Characteristics of Broiler Chickens with Different Growth Potential and Submitted to Heat Stress deposited more crude protein and less ether extract in their carcasses than PCLC ones, except in group $\mathrm{Ad}_{23^{\prime}}$ where both lines deposited the same percentage of fat. The few studies available in literature comparing the differences between genetically selected and nonselected broilers report opposite results for fat deposition. Havestein et al. (1994b) described higher fat accretion in selected broilers at 43 days; however, fat percentage was not different between the two genetic groups at the market age (43 days for selected and 85 days for non-selected broilers), showing that genetic improvement increased only the rate of fat deposition in modern broilers.

\begin{tabular}{|c|c|c|c|}
\hline \multirow{2}{*}{ Variables } & \multirow{2}{*}{ Pair-feeding scheme } & \multicolumn{2}{|c|}{ Genetic group } \\
\hline & & PCLC & AgRoss 308 \\
\hline \multirow{3}{*}{ Crude protein } & $\mathrm{Ad}_{23}$ & $50.6 \pm 0.3^{b B}$ & $51.2 \pm 0.5^{\mathrm{CA}}$ \\
\hline & $\mathrm{Pf}_{23}^{23}$ & $52.8 \pm 0.5^{a B}$ & $56.6 \pm 0.2^{\mathrm{aA}}$ \\
\hline & $\mathrm{Ad}_{32}^{23}$ & $48.0 \pm 0.2^{с B}$ & $51.9 \pm 0.3^{\mathrm{bA}}$ \\
\hline \multirow[t]{3}{*}{ Ether extract } & $\mathrm{Ad}_{23}$ & $39.6 \pm 0.3^{\mathrm{bA}}$ & $40.7 \pm 0.3^{\mathrm{aA}}$ \\
\hline & $\mathrm{Pf}_{23}^{23}$ & $37.9 \pm 0.5^{\mathrm{CA}}$ & $34.7 \pm 0.3^{\mathrm{cB}}$ \\
\hline & $\mathrm{Ad}_{32}$ & $43.6 \pm 0.5^{\mathrm{aA}}$ & $40.1 \pm 0.3^{\mathrm{bB}}$ \\
\hline \multicolumn{4}{|c|}{$\begin{array}{l}\text { Different lower-case letters indicate difference }(p<0.05) \text { for the } \\
\text { contrasts } \mathrm{Ad}_{32} \text { versus } \mathrm{Pf}_{23} \text { (effect of heat exposure) and } \mathrm{Ad}_{23} \text { versus } \\
\mathrm{Pf}_{23} \text { (effect of reduced feed intake generated by heat exposure); } \\
\text { different upper-case letters indicate difference }(p<0.05) \text { between } \\
\text { genetic groups. }\end{array}$} \\
\hline
\end{tabular}

\section{Abdominal fat allometric coefficient $(\beta)$}

There was no significant interaction between pairfeeding scheme and genetic group for abdominal fat allometric coefficient $\beta$ at 42 days. Moreover, all estimates showed $\beta>1(p<0.05)$, clearly indicating that broilers deposited abdominal fat in a higher rate than their whole carcass grew. Analyzing the differences between genetic groups, the lower allometric coefficient $\beta$ in the selected line evindences that PCLC broilers deposited abdominal fat faster than AgRoss 308 ones. This finding is opposite to that described by Harvestein et al (1994b); however, it is important to notice that, in the present trial, the experimental diets were formulated according to AgRoss 308 requirements. Therefore, the higher rate of abdominal fat deposition in PCLC broilers may be attributed to excessive energy uptake, as their metabolizable energy requirement is probably lower than the energy level offered in the diet.

The pair-feeding scheme also affected abdominal fat deposition rate $(p<0.05)$. Thus, allometric coefficient $\beta$ increased due to a direct effect of temperature (contrast $\mathrm{Ad}_{32}$ versus $\mathrm{Pf}_{23}$ ), and decreased due to feedintake reduction imposed by heat exposure (contrast $\mathrm{Ad}_{23}$ versus $\mathrm{Pf}_{23}$ ). Literature is conclusive in regard to the higher fat deposition for heat-exposed broilers and to the reduction in fat accretion due to feed restriction (Howlider \& Rose, 1987; Faria Filho, 2006). In addition, these findings agree and in part explain our results of whole-carcass chemical composition.

\section{CONCLUSIONS}

In both genetic groups, both environmental temperature and feed-intake restriction influenced abdominal fat deposition rate and other carcass traits; however, the impact of heat exposure on broiler performance is more marked on the selected line. Consequently, modern broiler production systems need to provide better environmental conditions for maximizing activity profitability.

\section{REFERENCES}

Abu-Dieyeh ZHM. Effect of high temperature per se on growth performance of broilers. International Journal of Poultry Science 2006; 5:19-21.

Ain Baziz H, Geraert PA, Padilha JCF, Guillaumin S. Chronic heat exposure enhances fat deposition and modifies muscle and fat partition in broiler carcasses. Poultry Science 1996; 75:505-513.

AOAC Association of Official Analytical Chemists. Official Methods of Analysis of the Association of Official Analytical Chemists. $15^{\text {th }}$ ed., Washington (DC); 1990.

Arjona AA, Denbow DM, Weaver Jr WD. Effect of heat early in life on mortality of broilers exposed to high environmental temperatures just prior to marketing. Poultry Science 1988; 67:226-231.

\begin{tabular}{lccccc}
\hline Table 5 - Abdominal fat allometric coefficient $\beta$ of & 42 -day-old broilers. & & & \\
Genetic group & Pair-feeding scheme & $\alpha^{*}$ & $\beta^{* *}$ & $\mathbf{P}^{*}$ & $\mathbf{R}^{\mathbf{2}}$ \\
PCLC & - & -9.4598 & $1.75857^{\mathrm{a}}$ & $<0.0001$ & 0.954 \\
AgRoss 308 & - & -8.2172 & $1.54423^{\mathrm{b}}$ & $<0.0001$ & 0.918 \\
- & $\mathrm{Ad}_{23}$ & -8.2551 & $1.55930^{\mathrm{a}}$ & $<0.0001$ & 0.931 \\
- & $\mathrm{Pf}_{23}$ & -6.9697 & $1.37446^{\mathrm{b}}$ & 0.0005 & 0.872 \\
- & $\mathrm{Ad}_{32}$ & -9.1959 & $1.71250^{\mathrm{a}}$ & $<0.0001$ & 0.939 \\
\hline
\end{tabular}

Fitted equation: $\log y$ (abdominal fat) $=\alpha+\beta$ [log $x$ (body weight)]. *All alpha values are different from 0 (Student $\mathrm{t}$ test, $\mathrm{p}<0.05) .{ }^{* *}$ All beta values are higher than 1 (Student's t-test, $p<0.05$ ); different letters indicate difference among variation sources (Student's t-test, $p<0.05$ ). 
Aksit M, Yalcin S, Ozkan S, Metin K, Ozdemir D. Effects of temperature during rearing and crating on stress parameters and meat quality of broilers. Poultry Science 2006; 85:1867-1874.

Bonnet S, Geraert PA, Lessire M, Carre B, Guillaumin S. Effect of high ambient temperature on feed digestibility in broilers. Poultry Science 1997; 76:857-863.

Chambers JR, Gavora JS, Fortin A. Genetic changes in meat-type chickens in the last twenty years. Canadian Journal of Animal Science $1981 ; 61: 555-563$.

Deaton JW, Reece FN, Branton SL, May DJ. High environmental temperature and broiler livability. Poultry Science 1986; 65:12681269.

Faria Filho DE. Aspectos produtivos, metabólicos, econômicos e ambientais da nutrição protéica para frangos expostos ao calor [tese]. Jaboticabal (SP): Universidade Estadual Paulista; 2006.

Furlan RL, Macari M. Termorregulação. In: Macari M, Furlan RL, Gonzales E. Fisiologia aviária aplicada a frangos de corte. $2^{\text {nd }}$ ed. Jaboticabal : Funep; 2002. p. 209-230.

Geraert PA, Guillaumin S, Leclercq B. Are genetically lean broilers more resistant to hot climate? British Poultry Science 1993; 34: 643-653.

Geraert PA, Padilha JCF, Guillaumin S. Metabolic and endocrine changes induced by chronic heat exposure in broiler chickens: growth performance, body composition and energy retention. British Journal of Nutrition 1996a; 75:195-204.

Geraert PA, Padilha JCF, Guillaumin S. Metabolic and endocrine changes induced by chronic heat exposure in broiler chickens: biological and endocrinological variables. British Journal of Nutrition 1996b; 75:205-216

Havenstein GB, Ferket PR, Scheideler SE, Larson BT. Growth, livability, and feed conversion of 1957 vs 1991 broilers when fed "Typical" 1957 and 1991 broiler diets. Poultry Science 1994a; 73:17851794.

Havenstein GB, Ferket PR, Scheideler SE, Rives DV. Carcass composition and yield of 1991 vs 1957 broilers when fed "Typical" 1957 and 1991 broiler diets. Poultry Science 1994b; 73:17951804.

Howlider MA, Rose SP. Temperature and the growth of broilers. World's Poultry Science Journal 1987; 43:228-237.

Huxley JS. Problems of relative growth. New York (NY): Dial Press; 1932.

Huxley JS, Teissier G. Terminology of relative growth. Nature 1936; 137:780-781.

Koh K, Macleod MG. Effects of ambient temperature on heat increment of feeding and energy retention in growing broilers maintained at different food intakes. British Poultry Science 1999; 40:511-516.
Leenstra F, Cahaner A. Effects of low, normal, and high temperatures on slaughter yield of broilers from lines selected for high weight gain, favorable feed conversion, and high or low fat content. Poultry Science 1992; 71:1994-2006.

Littell RC, Stroup WW, Freund RJ. SAS for Linear Models. $4^{\text {th }}$ ed. Cary (NC): SAS Institute; 2002.

Macleod MG. Effects of amino acid balance and energy: protein ratio on energy and nitrogen metabolism in male broiler chickens. British Poultry Science 1997; 38:405-411.

NRC, National Research Council. Nutrient requirements of poultry. Washington: National Academy Press; 1994.

Oliveira Neto AR, Oliveira RFM, Donzele JL, Rostagno HS, Ferreira RA, Carmo HM, Gasparino E. Efeito da temperatura ambiente sobre o desempenho e características de carcaça de frangos de corte alimentados com dieta controlada e dois níveis de energia metabolizável. Revista Brazileira de Zootecnia 2000; 29:183-190.

Sakomura NK, Longo FA, Oviedo-Randón EO, Boa-Viagem C, Ferraudo A. Modeling energy utilization and growth parameter description for broiler chickens. Poultry Science 2005; 84:13631369.

Temim S, Chagneau AM, Guillaumin S, Michel J, Peresson R, Geraert $P A$, Tesseraud S. Effects of chronic heat exposure and protein intake on growth performance, ntrogen retention and muscle development in broiler chickens. Reproduction Nutrition Development 1999; 39:145-156.

Temim S, Chagneau AM, Peresson R, Teseraud S. Chronic heat exposure alters protein turnover of three different skeletal muscles in finishing broiler chickens fed 20 or $25 \%$ protein diets. Journal of Nutrition 2000; 130:813-819.

Yahav S, Mcmurtry JP. Thermotolerance acquisition in broiler chickens by temperature conditioning early in life - the effect of timing and ambient temperature. Poultry Science 2001; 80: 16621666. 